\title{
DONOR RISK INDEX VARIATION OF DECEASED DONOR IN LIVER TRANSPLANTATION BETWEEN OFFERING OPO
}

\section{Variação do índice de risco de doador falecido em transplante de fígado entre OPO ofertantes}

\author{
Fábio Silveira, Fábio Porto Silveira, Cassia Regina Sbrissia Silveira, Ricardo Teles Schulz, \\ Ana Sofia Jaramillo Montero; Henrique Cesar Higa
}

\begin{abstract}
Introduction: Geographical disparities, quantity and quality of organs may result in different liver acceptance patterns among transplant teams. Purpose. To determine the standard quality of the organ in cadaveric liver transplantation, according to the region of the supply and the clinical status of the recipient. Methods: We used the variation of the donor risk index (DRI) of the 4 OPO in Paraná (Curitiba, Maringá, Londrina and Cascavel) and national OPO. The sample included all adults undergoing liver transplantation from deceased donor between November, 2015 and February $2019(n=135)$, in a single center. Results: The mean DRI of patients was 1.37 (interquartile range [IIQ] 1.091.59). Mean DRI per offering OPO ranged from 1.26 to $1.76(p<0.05)$. The average DRI (1.76) of organs offered by the National OPO exceeded the IIQ of the DRI of other OPOs. There was no difference in age (mean 50.4 \pm 11.54$)$ and SOFA (mean 9.78 \pm 2.14$)$. Time of cold ischemia of the national OPO $(496 \pm 74.58 \mathrm{~min})$ was significantly longer, but did not exceed $75 \%$ of other OPOs. Organ recipients offered by the National OPO had significantly lower MELD (18 \pm 4.78$)$. Positive linear correlation between receptor MELD and DRI was observed, without attaining statistical significance. Conclusions: The mean DRI and its interquartile amplitude of organs accepted for transplantation in our service is similar to transplanted organs in the USA, Europe and Brazil. Patients with significantly lower MELD received organs with higher DRI.
\end{abstract}

Keywords: Liver Transplantation; Risk Index; Organ Donors.

Instituições:

Centro Digestivo e Transplante de Órgãos / Hospital do Rocio Campo Largo/PR - Brasil.

\section{Correspondência:}

Fábio Silveira

Estrada da Cachoeira 1000, casa 9. Campo Largo/PR

(41) 99691-1866

fabiosilveira@cdto.med.br

Recebido em: 05/10/2020

\section{INTRODUÇÃO}

Geographic disparities in the organ offer may result in different patterns of organ acceptance between liver transplant teams. Since 2010, the state of Parana, located in the South region of Brazil, through a series of local governmental policies, raised the organ donation rate from $8,9 \mathrm{pmp}$ to $47,7 \mathrm{pmp} .{ }^{1}$ This increase in the organ offer challenges the assistant physician whether to accept or refuse a graft, as the long term survival of liver transplant recipients is influenced by the recipient and graft characteristics. 
A useful tool for measuring the organ quality is the donor risk index (DRI) that combines factors such as donor age, mechanism of death and cold ischemia time (CIT) to predict the risk of graft failure. ${ }^{2}$ The interaction between recipient and graft characteristics is usually analyzed by a member of the transplant team, by the time of the organ availability. This is an area of significant medical incertitude, so is well known that there is a considerable variation in clinical practice.

According to the Brazilian legislation, an organ offer is first allocated to liver recipients listed within the state of the donor. The organ share only happens due to an emergency status or when the use of the organ is refused by local teams. Aforementioned difference in clinical practice may be influenced by non-clinical issues such as transplant volume and competition between transplant centers, and state government. ${ }^{3}$

Thus, the aim of this study was to determine the pattern of graft quality in liver transplantation from deceased donor, according to the region of the offer and the clinical status of the recipient.

\section{METHODS}

This study used the prospective database and included all patients who underwent liver transplantation at Hospital do Rocio, between November 2015 and February 2019. $(n=135)$. Table 1 brings patient characteristics.

Table 1 - Patient characteristics

\begin{tabular}{lc}
\hline Number of patients ( $\mathrm{n}$ ) & 135 \\
Age (years) \pm SD & $50,4 \pm 11,54$ \\
Sex (M/F) & $63,97 \% / 36,03 \%$ \\
MELD (lab) & $21,66 \pm 7,52$ \\
MELD (adjusted) & $24,02 \pm 9,06$ \\
MELD exception (\%) & $15,44 \%$ \\
\hline
\end{tabular}

Organ quality was calculated by using DRI, a continuous measure of the risk of graft failure which is composed by factors such as donor age, cause of death, CIT and place (national, regional or local). ${ }^{2}$ DRI calculation considered a local organ when the donation occurred in the same Organ Procurement Organization (OPO) of the transplant center (OPO Curitiba), a regional location whenever inside the Parana State (OPO Curitba, Londrina, Maringá, Cascavel) and National location (set as OPO National) when outside Paraná, irrespective of the donation state. The SOFA (Sequential Organ Failure Assessment) Score was used to determine the level of the organ dysfunction of the donor. ${ }^{4}$ The model for end stage liver disease (MELD) score was calculated immediately prior to transplant, not considering eventual exception status scores. Medical condition was depicted as non-hospitalized and hospitalized in the moment of organ allocation. For quantitative variables, analysis of variance (ANOVA) for parametric data and Kruskalwallis test for non-parametric. Data collection and analysis were performed by the epidemiological software Epilnfo $^{\text {TM }}$ (version 7.2.2.16, Center for Disease Control and Prevention). ${ }^{5}$ Statistical tests of significance when $p<0.05$.

\section{RESULTS}

Among 135 liver transplants performed along the studied period, the DRI distribution is shown in figure 1. The mean DRI in patient level was 1.37, median 1.33 and interquartile range 1.09-1.59. Mean DRI by OPO ranged from 1.26 to 1.76 , as shown in table 2 .

The mean DRI $(1,76)$ of the organs harvested from the National OPO exceeded the DRI interquartile range at the patient level and local OPOs. Mean DRI between OPOs attained statistical significance, with $\mathrm{p}<0,05$.

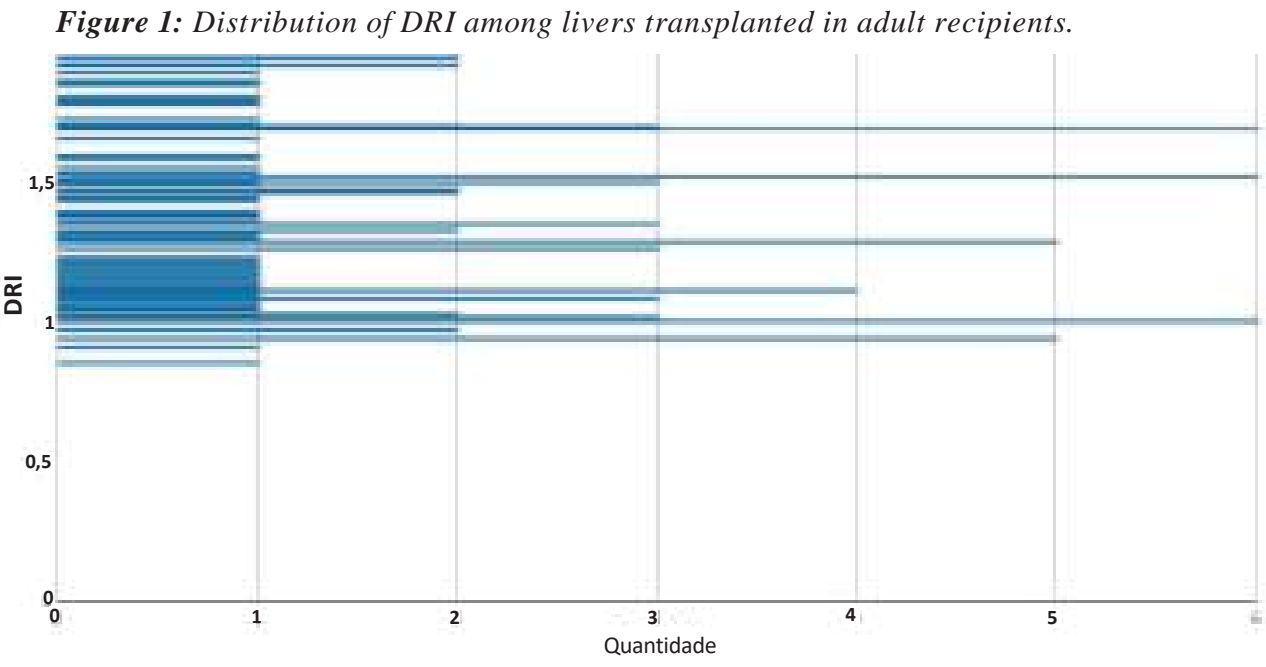


Fábio Silveira, Fábio Porto Silveira, Cassia Regina Sbrissia Silveira, Ricardo Teles Schulz, Ana Sofia Jaramillo Montero; Henrique Cesar Higa

Table 2 - DRI of transplanted livers according to the OPO of the donor

\begin{tabular}{lccc}
\hline & $\mathbf{n}(\%)$ & DRI & Interquartile range \\
\hline OPO Curitiba & $67(49,26 \%)$ & 1,2633 & $1,0190-1,4920$ \\
OPO Londrina & $13(9,56 \%)$ & 1,4338 & $1,2600-1,6890$ \\
OPO Maringá & $24(17,65 \%)$ & 1,4135 & $1,2555-1,6890$ \\
OPO Cascavel & $19(13,97 \%)$ & 1,4262 & $1,1030-1,6890$ \\
OPO National & $13(9,56 \%)$ & 1,7627 & $1,1110-1,9410$ \\
Patient (total) & 136 & 1,3766 & $1,0965-1,5905$ \\
\hline
\end{tabular}

$D R I=$ donor risk index $; \quad O P O=$ organ procurement organization.

Among other studied components of the DRI score, there was no significant difference in the donor age, but significant differences in the CIT (table 3). Mean CIT of National OPO did not exceed $75 \%$ of the local and regional OPOs.

Table 3 -Donors attributes and CIT according to the OPO of the donor

\begin{tabular}{|c|c|c|c|c|c|c|}
\hline & OPO Curitiba & OPO Londrina & OPO Maringá & OPO Cascavel & OPO National & p \\
\hline 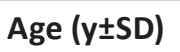 & $38,11 \pm 15,66$ & $40,23 \pm 17,10$ & $38,04 \pm 12,57$ & $39,47 \pm 16,90$ & $45,07 \pm 15,38$ & 0,6890 \\
\hline CIT (min) & $386 \pm 97,47$ & $469 \pm 64,16$ & $481 \pm 73,29$ & $471 \pm 64,45$ & $496 \pm 74,58$ & $0,0000^{*}$ \\
\hline SOFA & $9,72 \pm 2,31$ & $9,84 \pm 2,11$ & $9,7 \pm 2,33$ & $9,88 \pm 1,71$ & $10 \pm 1,73$ & 0,4830 \\
\hline ICU days & $3,68 \pm 2,29$ & $2 \pm 0,63$ & $3,1 \pm 1,3$ & $3,3 \pm 1,52$ & $4 \pm 3,97$ & 0,31 \\
\hline
\end{tabular}

$C I T=$ cold ischemia time; SOFA - Sequential Organ Failure Assessment; ICU-intensive care unit. Statistically significant results are in bold.

Regarding the severity of the liver disease, recipients who received organ from National OPO had significant lower MELD scores (table 4).

Table 4 - Severity of liver disease and offering OPOS.

\begin{tabular}{lcccccc}
\hline & OPO Curitiba & OPO Londrina & OPO Maringá & OPO Cascavel & OPO National & $\mathbf{p}$ \\
\hline MELD & $21 \pm 6,66$ & $19 \pm 10,77$ & $22 \pm 7,45$ & $25 \pm 8,22$ & $18 \pm 4,78$ & $0,04^{*}$ \\
Hospitalized (\%) & 47,76 & 23,08 & 45,83 & 47,37 & 46,15 & - \\
Urgent status & $4,48 \%$ & $0 \%$ & $8,33 \%$ & $10,53 \%$ & $15,83 \%$ & - \\
\hline
\end{tabular}

$M E L D=$ model for end stage liver disease. Statistically significant results are in bold.

The scatter diagram of the MELD and DRI scores shows a possible positive correlation between variables, but not significant $(p=0,6151)$ in linear regression analysis (figure 2$)$.

Figure 2 -

Scatter chart of DRI $x$ MELD

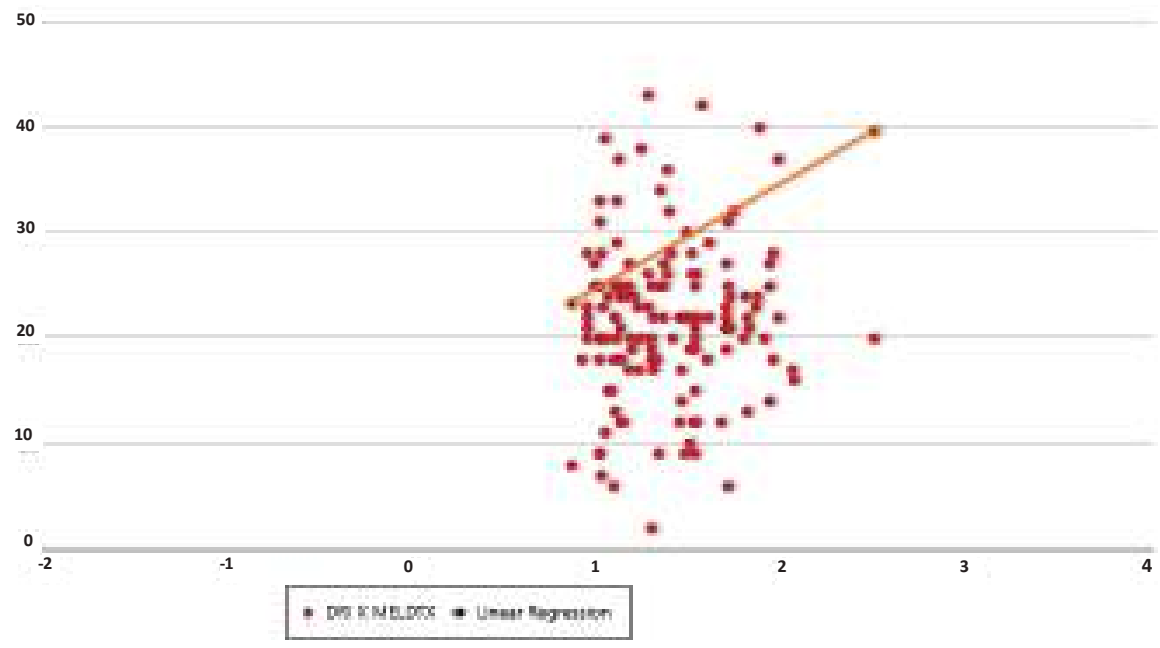




\section{DISCUSSION}

The limited supply of donor organs represents a challenge to the transplant community, since the concept and ethics of rationing in Medicine is almost exclusive to this area. ${ }^{6}$ Brazilian current allocation policies designate the available organ within a state to the sickest patient, represented by the highest MELD score. The decisionmaking process of acceptance or refusal of the use of an organ is complex, centered in the physician, but subjected to economical and regulatory interferences.

Nowadays, Paraná has the highest donation rate in Brazil, and the current organ availability poses to the liver transplant teams two challenges: not to refuse a potential good graft (consequence of the high availability) nor the use of an inadequate graft (consequence of the competition between centers, regulatory demands and ethical sense). ${ }^{7}$

Measuring graft quality is not an easy task, as it is influenced by some physical, biochemical and hemodynamic characteristics, macroscopic features during the organ retrieval, experience of the harvesting surgeon and transport logistics. Besides those difficulties, DRI is a tool for measuring the graft quality. Based on this observational study, we concluded that the mean DRI $(1,3766)$ of the transplanted organs harvested in our state, the interquartile range $(1,0965-1,5905)$ is similar to the transplanted organs in USA, ${ }^{8,9}$ Europe ${ }^{10}$ and Brazil. ${ }^{11}$

The physician dealing with mortality on the waiting list is prone to assume a higher organ risk to the sickest patient2 and this positive correlation was observed in our study (figure 2), even if not attaining statistical significance. The lack of statistical significance may be explained by the relative low number of donors, but mainly because we cannot predict the time or quality of an offer, associated with a narrow margin for recipientgraft matching, necessarily imposed by the regulatory rules. Lower DRI grafts are more likely to be accepted in the first position, irrespective the risk of the recipient. However, the acceptance of a non-ideal graft might be subject to a higher variation. ${ }^{2}$

An exception of this observation is the clinically debilitated, but low MELD score recipients. Clinical practice shows undeniably that in some patients, the MELD score does not accurately reflect their mortality risk, thus leading the medical practice to allocate high risk organs in patients with low MELD scores. ${ }^{8,9}$ Apart from urgent cases, usually national offers represent donor organs already refused by the local teams, inferring in lower quality organs. This behavior seems to be followed in the present study, since the mean MELD score of recipients graced with a liver from the National OPO was lower than the regional OPOs (table 4). This pattern of conduct have received some criticism, with data showing inferior post-transplant outcomes ${ }^{8,13}$ and increased costs to transplant centers. ${ }^{14}$

The observed difference in DRI regarding national OPO may be explained by the statistical significant difference in CIT, as no differences were observed in the donors' status when it is analyzing the age, SOFA and the number of ICU days (table 3 ). Finally, potential factors of influence and components of DRI, as cause of death, race and height of the donor were not individually analyzed in this study. Other components of the DRI, such as partial/split grafts and DCD donors would not interfere, as these modalities of transplant were not performed in our institution.

\section{CONCLUSION}

In conclusion, we can state that we have a homogeneous policy of liver graft acceptance in our team, with similar pattern of perceived risk of graft failure represented by DRI, when compared with other institutions or transplant systems. DRI use may facilitate the identification of disparities in the organ use, enabling observation of the transplant practices.

\section{ACKNOWLEDGMENT}

The authors would like to thank the families of donors who expressed authorization to give the organs. To the State Transplant System and to all the coordinators of OPOs and CIHDOTTs of the State of Paraná that through tireless effort allow the identification and realization of the entire process that allows the existence of an effective donor. 
Fábio Silveira, Fábio Porto Silveira, Cassia Regina Sbrissia Silveira, Ricardo Teles Schulz, Ana Sofia Jaramillo Montero; Henrique Cesar Higa

\section{RESUMO}

Introduction: Disparidades geográficas, quantidade e qualidade dos órgãos podem resultar em diferentes padrões de aceite de fígados entre equipes transplantadoras. Objetivo: Determinar o padrão de qualidade do órgão no transplante hepático cadavérico, de acordo com a região da oferta e o status clínico do receptor. Métodos: Utilizamos a variação do índice de risco do doador (DRI), por OPO ofertante no estado do Paraná (Curitiba, Maringá, Londrina e Cascavel) e da OPO Nacional. A amostra incluiu todos os adultos submetidos a transplante hepático de doador falecido entre novembro de 2015 e fevereiro de $2019(n=135)$, em um único centro. Resultados: O DRI médio dos pacientes foi de 1,37 (intervalo interquartil [IIQ] 1,09-1,59). O DRI médio por OPO ofertante variou de 1,26 a 1,76 ( $p<0,05)$. O DRI médio $(1,76)$ dos órgãos ofertados pela OPO Nacional excedeu o IIQ do DRI das demais OPO. Não houve diferença na idade (média $50,4 \pm 11,54)$ e SOFA (média 9,78 $\pm 2,14$ ). Tempo de isquemia fria da OPO nacional $(496 \pm 74,58 \mathrm{~min}$ ) foi significativamente maior, porém não excedeu $75 \%$ das demais OPO. Receptores de órgãos ofertados pela OPO Nacional possuíam MELD significativamente mais baixos $(18 \pm 4,78)$. Foi observada correlação linear positiva entre o MELD do receptor e DRI, sem atingir significância estatística. Conclusões: O DRI médio e sua amplitude interquartil dos órgãos aceitos para transplante em nosso serviço é semelhante aos dos órgãos transplantados nos EUA, Europa e Brasil. Pacientes com MELD significativamente mais baixos receberam órgãos com maior DRI.

Descritores: Transplante de Fígado; Indicador de Risco; Doador de Órgãos.

\section{REFERÊNCIAS}

1. RBT - Registro Brasileiro de Transplantes. ABTO Associação Brasileira de Transplante de Órgãos, 2018.

2. Feng S, Goodrich NP, Bragg-Gresham JL, Dykstra DM, Punch JD, DebRoy MA, et al. Characteristics associated with liver graft failure: the concept of a donor risk index. Am J Transplant. 2006 Apr;6(4):783-90.

3. Flores A, Asrani SK. The donor risk index: A decade of experience. Liver Transpl. 2017 Sep;23(9):1216-25.

4. Schrem H, Reichert M, Reichert B, Becker T, Lehner F, Kleine $\mathrm{M}$, et al. Value of the SOFA score as a predictive model for short-term survival in high-risk liver transplant recipients with a pre-transplant labMELD score $>/=30$. Langenbecks Arch Surg. 2012 Jun;397(5):717-26.

5. Dean AG AT, Sunki GG, Friedman R, Lantinga M, Sangam S, Zubieta JC, Sullivan KM, Brendel KA, Gao Z, Fontaine N, Shu M, Fuller G, Smith DC, Nitschke DA, and Fagan RF. . Epi Info ${ }^{\mathrm{TM}}$, a database and statistics program for public health professionals. CDC, Atlanta, GA, USA. 2011.

6. Rhodes R, Miller C, Schwartz M. Transplant recipient selection: peacetime vs. wartime triage. Camb Q Healthc Ethics. 1992 Fall;1(4):327-31.

7. Halldorson JB, Paarsch HJ, Dodge JL, Segre AM, Lai J, Roberts JP. Center competition and outcomes following liver transplantation. Liver Transpl. 2013 Jan;19(1):96104.
8. Volk ML, Reichert HA, Lok AS, Hayward RA. Variation in organ quality between liver transplant centers. Am J Transplant. 2011 May;11(5):958-64.

9. Volk ML, Lok AS, Pelletier SJ, Ubel PA, Hayward RA. Impact of the model for end-stage liver disease allocation policy on the use of high-risk organs for liver transplantation. Gastroenterology. 2008 Nov;135(5):1568-74.

10. Blok JJ, Braat AE, Adam R, Burroughs AK, Putter $H$, Kooreman NG, et al. Validation of the donor risk index in orthotopic liver transplantation within the Eurotransplant region. Liver Transpl. 2012 Jan;18(1):112-9.

11. Meine MH, Leipnitz I, Zanotelli ML, Schlindwein ES, Kiss G, Martini J, et al. Comparison Between IGL-1 and HTK Preservation Solutions in Deceased Donor Liver Transplantation. Transplant Proc. 2015 May;47(4):888-93.

12. Emond JC. Measuring access to liver transplantation: An overdue metric for center quality and performance. J Hepatol. 2016 Apr;64(4):766-7.

13. Schaubel DE, Sima CS, Goodrich NP, Feng S, Merion RM. The survival benefit of deceased donor liver transplantation as a function of candidate disease severity and donor quality. Am J Transplant. 2008 Feb;8(2):419-25.

14. Axelrod DA, Schnitzler M, Salvalaggio PR, Swindle J, Abecassis MM. The economic impact of the utilization of liver allografts with high donor risk index. Am J Transplant. 2007 Apr;7(4):990-7. 